BIS WORKING PAPERS

No. 66 - April 1999

\title{
EVOLVING INTERNATIONAL FINANCIAL MARKETS: SOME IMPLICATIONS FOR CENTRAL BANKS
}

by

William R White

BANK FOR INTERNATIONAL SETTLEMENTS

Monetary and Economic Department

Basle, Switzerland 
BIS Working Papers are written by members of the Monetary and Economic Department of the Bank for International Settlements, and from time to time by other economists, and are published by the Bank. The papers are on subjects of topical interest and are technical in character. The views expressed in them are those of their authors and not necessarily the views of the BIS.

Copies of publications are available from:

Bank for International Settlements

Information, Press \& Library Services

$\mathrm{CH}-4002$ Basle, Switzerland

Fax: +41 61 / 2809100 and +4161/2808100

This publication is available on the BIS website (www.bis.org).

(C) Bank for International Settlements 1999.

All rights reserved. Brief excerpts may be reproduced or translated provided the source is stated. 
BIS WORKING PAPERS

No. 66 - April 1999

\title{
EVOLVING INTERNATIONAL FINANCIAL MARKETS: SOME IMPLICATIONS FOR CENTRAL BANKS
}

by

William R White*

\begin{abstract}
Internationally integrated capital markets can have significant effects on the way central bankers pursue both monetary (macroeconomic) and financial stability. With respect to the former, countries are being pushed into corner solutions of either "immutably" fixed exchange rates or floating. While the proper choice depends on a country's circumstances, no regime is without its own problems. In this paper, some of the practical implications of floating are highlighted; in particular, how adoption of such a regime affects the transmission mechanism of monetary policy and the problems posed by volatile exchange rate expectations. As for the pursuit of financial stability, central bankers and other regulators must increasingly recognise the international dimension in their efforts to promote the health of financial institutions, financial markets and the infrastructure (legal, payment systems, etc.) which supports them. This international dimension affects the nature of the prudential policies adopted as well as the processes through which they are agreed. Finally, recognising that monetary stability and financial stability are two sides of the same coin (witness Mexico in 1995 and South Asia more recently), the paper concludes with some preliminary reflections on possible interactions between monetary and prudential policies in an internationally integrated world.
\end{abstract}

* I would like to thank, without in any way implicating, Stefan Gerlach and John Murray in particular as well as Craig Furfine, João Cabral dos Santos, Claudio Borio and Larry Schembri for their comments on this paper. A shorter version of the paper was presented on 22 October 1998 at the Great Minds for Great Business Lecture and Symposium at the Joseph L Rotman School of Management, University of Toronto, Canada. 



\section{Contents}

Introduction

1

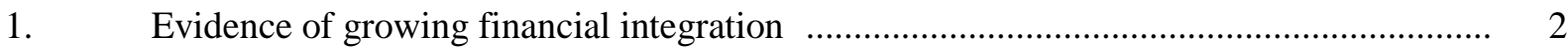

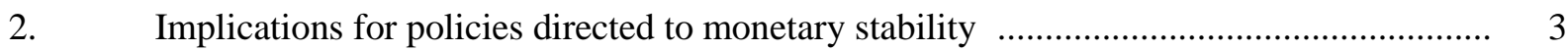

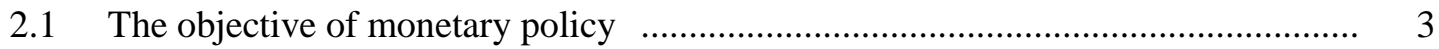

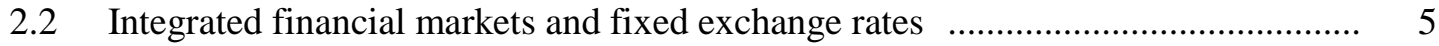

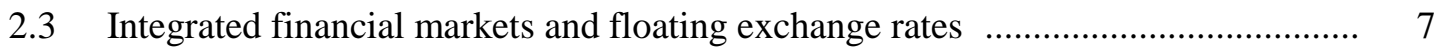

2.3.1 A different transmission mechanism for monetary policy ............................ 8

2.3.2 Problems of volatile exchange rate expectations ….................................... 10

2.4 Squaring the circle with capital controls? …...................................................... 15

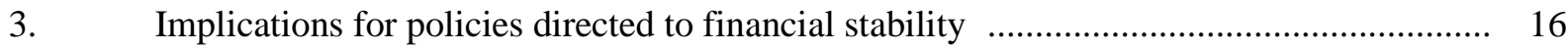

3.1 Micro policies to foster financial stability ...................................................... 18

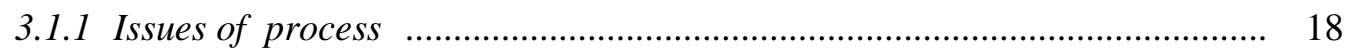

3.1.2 Issues of substance .......................................................................... 20

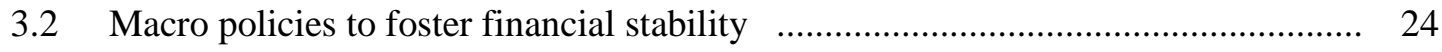

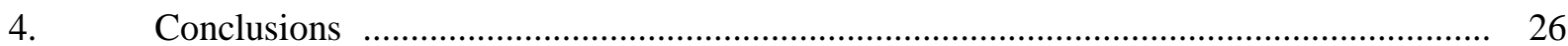

References 



\section{Introduction}

The world in which many central bankers live and implement their policies has changed dramatically over the last two decades. Perhaps the most important change has been the trend towards internationally integrated financial markets, in which domestic interest rates and asset prices become increasingly determined by international developments rather than solely by domestic factors. The manifestations of this trend are diverse and growing ever more apparent, particularly for emerging markets. ${ }^{1}$ A discussion of the practical implications of these developments for the pursuit of monetary and financial stability, both traditional preoccupations of central banks, provides the central theme of this paper. The principal conclusion is that central bankers and other policymakers interested in pursuing national interests must increasingly consider the international implications of their actions. Internationally integrated capital markets provide new freedom but also new limitations and policy complications, for larger countries as well as small ones.

As a Canadian, I recognise that some of what follows will seem very familiar to a Canadian audience. We have been blessed and burdened with capital markets that have been fully integrated with those of the United States for many decades. Moreover, the Mundell-Fleming model has for more than 30 years provided Canadians with a rough guide to the limitations of both domestic monetary and fiscal policy in such an integrated financial world. Put bluntly, monetary policy is ineffective in influencing spending under a fixed exchange rate regime, while fiscal policy loses its countercyclical potency under flexible exchange rates. ${ }^{2}$

Yet it would be unwise to assume that all the theory is in place and only needs to be applied on a larger global canvas. The recent experiences of Mexico and many Asian countries underline the need to better understand the complications created by high debt levels and unstable expectations about exchange rates and asset prices, neither of which were explicitly considered in the Mundell-Fleming model. Moreover, these experiences have made clear how international capital flows may have more disruptive effects in emerging markets than in industrial ones given their often more volatile macroeconomic environment and weak financial systems. ${ }^{3}$ While I treat separately in this paper the changing role of central banks with respect to monetary and financial stability, recent history should teach us that they are really two sides of the same coin. Indeed, the paper concludes with some

1 The capital markets of the major industrial economies were already highly integrated by the 1970s. See Murray and Khemani (1989).

2 The standard Mundell-Fleming model is discussed in many textbooks, e.g. Rivera-Batiz and Rivera-Batiz (1995).

3 This does not imply that international capital flows "caused" the Asian crisis. In White (1998a), I summarise those sections of the 68th BIS Annual Report dealing with the recent Asian crisis. The conclusion drawn there is that the crisis has its roots in domestic failings, although international capital flows have clearly exacerbated those difficulties. 
reflections on how prudential regulations might contribute to macroeconomic stability and how monetary policy might be influenced by concerns about financial stability.

\section{Evidence of growing financial integration}

One indicator of growing international financial integration has been the sharp expansion in the scale of both gross and net capital flows between developed countries, and between developed and emerging markets. For example, balance-of-payments statistics indicate that net inflows into emerging economies rose from virtually zero in 1989 to reach $\$ 307$ billion in 1996, before falling to about half that level in 1997 and $1998 .{ }^{4}$ Increased international financial flows have been matched by a growing penetration of domestic markets by foreign financial institutions. There are over 700 foreign banks in the United States and over 500 in the United Kingdom, and many emerging economies (particularly in Latin America) are clearly moving to more openness in this regard.

Another indicator of growing integration has been the creation of new markets and instruments to facilitate international transactions. Offshore markets are increasingly allowing transactions in domestic currencies to be conducted abroad. ${ }^{5}$ It is also noteworthy that domestic European and (until recently) Asian financial markets have been growing significantly faster than more mature markets in North America. Further, a whole host of new financial instruments have been developed to allow both borrowers and lenders to obtain precisely the combination of return, risk and liquidity that they desire. In response to these possibilities, the outstanding notional value of exchange-traded derivative instruments rose to $\$ 13.5$ trillion by end-March 1998 and average daily turnover in foreign currency markets rose to $\$ 1.5$ trillion by April 1998 according to the latest BIS survey. ${ }^{6}$ With single firms operating worldwide and books being transferred across time zones, highly interdependent markets in many financial instruments now operate 24 hours a day. As a corollary to these developments, the volume of transactions in related systems for payments and settlements now amounts to over $\$ 10$ trillion a day, ${ }^{7}$ with potential implications for systemic stability and thus a new source of concern for central banks.

It is important to note the reasons for this expansion, because it is fundamental and not likely to be reversed or easily resisted. While the catalyst for the growth of international capital flows was the

4 See IIF (1998). It should be noted, however, that net inflows to emerging economies had fallen to very low levels by the end of the 1980s owing to the previous debt crisis. Thus, the secular trend towards growing capital flows is overestimated by data which reflect this cyclical complication.

5 See Galati (1998) and BIS (1997), p 92.

6 See BIS (1998a).

7 See BIS: CPSS (1998). 
current account imbalances of the 1970s (including those associated with the OPEC shocks), subsequent developments have been driven in large part by technological advances and reductions in communications costs. The fact that certain kinds of financial transaction have become both possible and cost-efficient has been a powerful engine feeding growth in demand for these products. Deregulation of the financial sector in both developed countries and emerging economies has also played an important role in supporting these trends. In large part this has been a deliberate attempt to reap the efficiency gains of more open, liberalised financial markets. However, in some instances deregulation has also been a response to the reality that previous regulations were being circumvented in various ways.

Viewed from the perspective of either longer-run efficiency or what is practically feasible, reregulation would not seem to be a longer-run solution to the new problems which internationally integrated financial markets pose for central bankers. Indeed, between 1995 and 1997 efforts were being made to amend Article VIII of the IMF Charter to further encourage the free flow of international capital. Yet the recent crises in Mexico and Asia have also reminded us that rapid liberalisation of the capital account can bring attendant dangers, particularly when the domestic financial infrastructure (including the legal infrastructure) and supervisory apparatus are inadequate. Again, these are new sources of interest and concern to central bankers in many parts of the world.

\section{Implications for policies directed to monetary stability}

\subsection{The objective of monetary policy}

A striking feature of recent years has been the growing acceptance by central bankers in industrial countries of the view that monetary policy should be directed to the achievement of domestic price stability, where the "price" referred to is that of some currently produced or consumed product. ${ }^{8}$ In part, this reflects a belated recognition that there is no long-run trade-off between inflation and unemployment. Central banks, whose only monetary instrument is the size of their own balance sheet (the capacity to control the level of bank reserves), can sustainably hit only one target and that target must be a nominal one. Perhaps more importantly, this new focus reflects decades of bad experience during which central banks tried and failed to exert a lasting influence on real variables such as the rate of unemployment, the real exchange rate and the trade balance. In short, history seems to have shown that central banks can control prices and they cannot over the long run control anything else.

8 In many industrial countries, following a trend begun in New Zealand and Canada in the early 1990s, central banks pursue publicly announced "inflation targets". In some other countries, such as the United States, the objective is less transparent but still centred around a similar concept of price stability. For an overview of inflation targeting, see Bernanke et al (1998). 
During the 1980s and most of the 1990s, the search for price stability was almost synonymous with reducing inflation to low levels and keeping it there. This reflected the growing conviction, based on recent historical experience, that inflation is costly in terms of both reduced economic efficiency and increased uncertainty. ${ }^{9}$ Moreover, in a world of accelerating change and associated social stresses, inflation was felt to be exacerbating such stresses, echoing points first made by Keynes (1923) in $A$ tract on monetary reform when the United Kingdom was undergoing profound economic and social change in the aftermath of the First World War. In the last year or two, as the threat of inflation has receded in many countries and the threat of deflation has risen globally, the pursuit of price stability has increasingly been viewed in a more balanced way. Whether described in terms of a "symmetric response" to deviations of inflation from target bands, or the explicit assumption of "price level stability", there is a growing recognition that monetary policy can be too tight as well as too easy. ${ }^{10}$

Since pressures on prices have much to do with output "gaps", this focus on price stability does not imply that central bankers no longer care about cyclical stabilisation. ${ }^{11}$ If prices begin to rise unacceptably for cyclical reasons, interest rates would still rise to offset such pressures. In the same fashion, cyclical shortfalls of demand, rising unemployment and falling prices or excessively rapid disinflation would be met by easier monetary conditions. Trying to fine-tune the unemployment rate over the cycle would then provide little, if any, benefits in terms of improved labour market developments over the cycle, while likely leading to the significant costs associated with higher inflation over time.

Being part of an internationally integrated financial system should not in principle affect the choice of a domestic objective for monetary policy. However, it will clearly affect the means chosen to achieve it. Highly mobile capital flows make the use of variable-peg exchange rate regimes - to import price stability - more difficult to sustain and push the authorities in the direction of either an "immutable" fix or managed floating. For examples of the former response, one might consider the introduction of the euro in the context of economic and monetary union in Europe, the introduction of currency boards in a number of countries ${ }^{12}$ and recent suggestions that Argentina might "dollarise" its economy if currency pressures persisted. For examples of the latter, consider the experiences of some of the currencies pegged to (or shadowing) the Deutsche mark as it strengthened for cyclical reasons in the

9 For discussion of the effects of inflation on growth, see, among others, Barro (1995), Bruno and Easterly (1995), de Gregorio (1996), Fischer (1993), Sarel (1996) and Selody (1990).

10 There may still be some cross-Atlantic asymmetry, reflecting the defining and different historical experiences of hyperinflation in Europe in the 1920s and the Great Depression in North America.

11 This point is worth repeating given recent statements by Finance Ministers in Europe bearing on the policy objectives of the European Central Bank. Svensson (1997) shows formally that central banks that aim to stabilise prices will react to all determinants of inflation, including the output gap.

12 Perhaps the best-known exponent of this approach is Steve Hanke, who had a highly visible presence in the early days of the Indonesian crisis. See Hanke et al (1993). 
early 1990s. More recently, consider the similar experience of many Asian countries whose currencies were previously pegged to a US dollar which was also strengthening for cyclical reasons. In most, although not all, cases, countries were forced to adopt floating exchange rate regimes which generally continue to prevail. And most recently, of course, we have the experiences of both the Russian and Brazilian currencies, which were forced to devalue in August 1998 and December 1998 respectively.

There are clearly many merits to the fixed exchange rate option, provided of course that the "fix" is to a country which is pursuing a reasonable domestic objective for its own monetary policy and is subject (more or less) to the same kind of real shocks. ${ }^{13}$ However, the fixing country must also have all the prerequisites in place to maintain the peg. Unfortunately, the list of such requirements - a sound fiscal policy, a high domestic saving rate, a robust banking system, and a limited degree of exposure to external shocks - seems to be growing with each successive crisis. While the experience of a large number of European countries (and a few currency boards) over the last few years would seem to show that such a strategy can be followed successfully, the relative stability of the euro-11 currencies was materially supported by anticipation of the introduction of the euro. Reliance on such an anchor cannot be a common event.

Should a country rather choose (or have thrust upon it) the option of managed floating, the desirability of choosing domestic price stability as the objective of monetary policy is significantly enhanced, since a nominal anchor of some sort is needed. This combination of a floating exchange rate system allied with a commitment to domestic price stability has been advocated by many "smallish" open economies in recent years (including Canada, the United Kingdom, Australia, New Zealand and Sweden) and is implicit in the regime proposed for EMU, taken as a single currency area. Moreover, it also has important historical antecedents. When Sweden was forced off the gold standard, this was precisely the combination suggested by an illustrious advisory panel including Gustav Cassell, David Davidson and Eli Hecksher, ${ }^{14}$ and it was effectively what Keynes (1923) recommended to the UK Treasury rather earlier as an alternative to a return to the gold standard in Britain.

\subsection{Integrated financial markets and fixed exchange rates}

Whether a country chooses a fixed or a floating exchange rate regime, highly mobile capital flows can have significant effects on how monetary policy is conducted. In the former case, it is perhaps not really appropriate to talk about longer-run effects since domestic monetary policy is determined elsewhere over such a time frame. Yet it is still fair to say that capital flows can have short-run

13 If the latter condition is violated, then real shocks (given a fixed nominal rate regime) must be absorbed through movements in domestic costs and prices. This could sometimes require unwelcome movements in such real variables as the unemployment rate.

14 Berg and Jonung (1998) discuss the episode of price level targeting in Sweden in the 1930s. See also Jonung (1992) and (1979). 
macroeconomic implications to which the monetary authority must respond. Capital inflows, for example, are inherently expansionary under fixed exchange rates because the monetary authority must, in the first instance, expand the supply of bank reserves to purchase the inflow at the fixed exchange rate. In principle, sterilisation of these inflows should be possible because foreigners' demand for domestic assets can be met by a sale of government paper at unchanged prices. In practice, however, such sterilisation is not always feasible. Moreover, governments are sometimes reluctant to accede to sterilisation (when it is feasible) because of the fiscal costs associated with such a policy. If accumulated reserves can only be invested at a lower nominal interest rate abroad than the domestic cost of financing the government, sterilisation implies that the government deficit will rise. ${ }^{15}$

Even worse, imperfect capital markets in emerging economies can sometimes lead to a vicious circle in the face of capital inflows. Governments must issue more paper to sterilise inflows but, if foreign demand is initially for other forms of domestic assets, real interest rates may rise rather than fall as would normally be expected. While higher real rates might be thought disinflationary in themselves, they may in turn attract still more foreign capital, which further enhances the likelihood of unsterilised intervention and an undesired expansion of credit. ${ }^{16}$ This vicious circle argument clearly assumes that there is a separate credit channel contributing to inflation, but this may very well be the case in many emerging economies. Indeed, one clear lesson from the recent Mexican and Asian experiences is that the same confidence effects which contributed to large capital inflows can also lead to a sharp increase in the demand for credit even at higher nominal interest rates. ${ }^{17}$ This tendency to "over-optimism" mostly affected Mexican consumers, whereas in Asia investors in property, shares and fixed capital were more involved. Yet the effects on credit expansion and the boom-bust cycle were broadly the same.

If capital inflows under a fixed exchange rate regime can contribute to overheating and inflationary problems, their subsequent reversal can trigger developments leading to recession and higher unemployment. These tendencies may be exacerbated if the reversal is sudden and the withdrawal of bank reserves implicit in foreign exchange intervention cannot be adequately sterilised. While political events may suddenly shake confidence, ${ }^{18}$ shifting perceptions of weakness in the financial sector can also play a similar role. Financial fragility (in particular, due to overlending in domestic currency) may be increasingly seen as inhibiting the monetary authorities from raising domestic interest rates to

15 For a discussion of some problems of this sort, as perceived by the affected policymakers themselves, see BIS (1996a).

16 See Turner (1995), p 31.

17 See Goldstein and Turner (1996). See also BIS (1997), Chapter VII.

18 For example, in late 1994 a series of political assassinations in Mexico and fears of peasant revolts in the south acted as a catalyst to force the peso sharply lower. Around the same time, perceived political weakness in the governments of Canada, Sweden and Italy led to significant weaknesses in their respective currencies and a sharp widening of bond spreads in the face of larger fiscal deficits. See BIS (1996b). 
defend the currency, making the currency vulnerable to any attacks upon it. However, if domestic borrowers also have significant exposure in foreign currencies, as was again the case in Mexico and many Asian countries, any decline in the value of the currency will also feed back indirectly to the banking system as bank customers become insolvent in increasing numbers. ${ }^{19}$ This dual currency exposure creates a true dilemma for the monetary authorities. Moreover, in such circumstances of joint vulnerability and an associated increase in risk premia, the exchange rate may have to fall and domestic interest rates to rise substantially before a new equilibrium is found.

While currency board arrangements are rightly touted as implying a more credible commitment to the current exchange rate than a simple commitment to fix it, complications remain. If the banking system is weak, there is an important risk operating in a destabilising fashion. Strict adherence to currency board arrangements implies that the monetary authority is unable to act as lender of last resort. This increases the danger of financial collapse and the likelihood of a sudden shift in the policy regime to prevent this from happening. Attempts can of course be made to operate the system with somewhat more flexibility, as has indeed been attempted in recent years in both Hong Kong and Argentina. However, to the extent that such efforts undermine the credibility of the regime itself, they too have their downside. Such conflicting objectives may account for the rather different reactions of the Hong Kong and Argentine authorities to the most recent bouts of pressure on their currencies. In Hong Kong, efforts were made both to restrain interest rate increases and to limit the effects on stock prices by direct purchases. In sharp contrast, the Argentinians have suggested replacing the peso with the dollar.

A credible commitment to a fixed exchange rate regime can help to shock inflationary expectations downwards. However, a common problem associated with this strategy (due to insufficiently flexible domestic wages) is that the real exchange rate tends to rise, the trade deficit expands and this in turn renders the exchange rate regime less credible. Recognition of this problem has led some policymakers in recent years to attempt to define "exit policies" which would effect a smooth transition to a more flexible exchange rate regime. ${ }^{20}$ Suggestions to make a fix seem still more immutable may help increase the credibility of the current regime, but do not address directly the underlying issue of competitiveness, which has its roots in the labour market.

\subsection{Integrated financial markets and floating exchange rates}

Given all the problems posed by highly mobile capital flows in the context of a fixed exchange rate regime, the arguments for relying more on floating would seem strong. Yet, while floating is a

19 This further underlines the potential dangers of fixed exchange rate regimes in that the borrowing in foreign currency (at relatively low interest rates) was encouraged by the belief that the regime would be maintained.

20 In this regard, the Israel experience is very interesting. It should be noted, however, that the transitional process that country put in place took many years to implement. See Klein (1998). 
necessary condition for the pursuit of a domestic ${ }^{21}$ price objective, it is not without its own complications. The conduct of monetary policy, given financial markets which are highly integrated internationally, differs significantly from the conduct of monetary policy in a closed economy. In particular, the transmission mechanism of monetary policy is different and there may well be problems arising from volatile exchange rate expectations.

\subsubsection{A different transmission mechanism for monetary policy}

Under floating exchange rates, both interest rates and the exchange rate have effects on spending, and in turn on "gaps" and inflationary pressures. At a conceptual level, it has long been recognised that the effects of interest rates on spending are complex. Non-linear responses to simple interest rate shocks may be produced if traditional income and substitution effects interact with asset price and debt service effects; such effects become more probable as asset prices and debt levels rise, as has been the case recently in the United States and Canada. ${ }^{22}$ The effects of exchange rate changes on spending add yet another layer of complexity leading sometimes to unfamiliar results. A stronger exchange rate resulting from monetary restraint directly reduces spending (substitution effects) on domestically produced goods and services, and should have direct pass-through effects on the prices of exports, imports and substitutes for these products. However, terms-of-trade effects may tend to work in the opposite direction (gains arising from currency appreciation encourage spending ${ }^{23}$ ), as may similar effects arising from the existence of significant levels of external assets or liabilities denominated in foreign currency. By way of an example of unusual effects arising from exchange rate movements, it could be this combination of substitution and terms-of-trade effects which explains unusually low inflation in the United States (and the growing trade deficit) alongside strong consumer spending. Indonesia provides another example since the depreciation of its currency (albeit from a fixed as opposed to a floating level) seems on balance to have had contractionary effects through both of these terms-of-trade effects. In contrast, the substitution effect has been muted by the lack of trade credit, which has itself been a byproduct of the weaker financial system generated by exchange rate depreciation.

The fact that the exchange rate becomes part of the transmission mechanism, given international financial integration, has other implications. In particular, interest rates will have to rise less to ward off excessive expansion because of the complementary effects of exchange rate appreciation. One unfortunate byproduct of this could well be the encouragement of domestic asset price increases, as

21 The emphasis here is on having a domestic price objective. Fixing the nominal exchange rate will eventually deliver the price objective of the other monetary authority, which may or may not be the same as the domestic objective which might have been chosen otherwise.

22 For a fuller examination of such issues, see BIS (1995b).

23 The consequences of a terms-of-trade shift depend importantly on whether it is thought to be temporary or permanent, with the bigger effect in the latter case. 
perhaps experienced in Japan in the late 1980s and more recently in the case of the United States (as the respective currencies strengthened). ${ }^{24}$ Harking back to the debate in the 1920 s between the Austrian and Cambridge (UK) schools, ${ }^{25}$ there are varying views as to the emphasis policymakers should put on such asset price increases. However, most contemporary central banks would agree that such increases are dangerous if fuelled by enough domestic credit expansion to call into question the health of the domestic banking system. This clearly became a massive problem in the Japanese case, while the implications for the United States of the recent acceleration in credit aggregates remain to be determined. The difficulties faced in 1998 by Long-Term Capital Management give some indication of the extent to which the banking sector in a number of countries may have become involved, at least indirectly, in the recent process of financial leverage. ${ }^{26}$

Another and more welcome implication of interest rates rising less than they might otherwise have done is that certain undesirable stock effects of monetary restraint will be reduced. Higher interest rates feed back into government debt service requirements and in turn to the structural deficit. Minimising this dynamic has clear advantages. In the same way, undesirable interest rate effects on capital stock accumulation will be reduced. Indeed, an appreciating exchange rate might even reduce the cost of capital (in spite of higher interest rates) if the import component of investment were high enough. However, another argument having to do with stock accumulation works in a less desirable direction. To the extent that the exchange rate rises, domestic producers become less "competitive", the trade deficit will deteriorate and the stock of foreign debt will rise. While the burden of foreign currency debt service may fall in the short term, due to the exchange rate appreciation itself, over time the rising stock of foreign debt will tend to reverse this movement.

There is no simple answer to this question of internal versus external balance. On the one hand, it is tempting to contend that the dilemma is false since, in the long run, monetary policy must be directed to nominal variables. Put otherwise, an attempt to resist appreciation on the grounds that it will reduce external competitiveness will lead eventually to a higher domestic cost structure, which will also reduce competitiveness. Viewed from this perspective, the deterioration in the trade account associated with currency appreciation should not be thought troublesome. It will be offset by a subsequent depreciation once enough slack has been produced in the domestic economy to ensure adequate disinflationary pressures. This was, broadly speaking, the experience of Canada from 1987 to 1993 and could potentially be the experience of the United States over the next few years. On the other hand, the recent experience of Mexico indicates clearly that these market adjustments to trade imbalances may not occur smoothly and that a policy of benign neglect may be dangerous. Contrary to

\footnotetext{
24 For a fuller examination of such issues, see BIS (1998c).

25 See Cochran and Glahe (1999).

26 For an analysis of this affair, see BIS: BCBS (1999a) and (1999b).
} 
the once fashionable "Lawson doctrine", even trade deficits arising from private sector decisions may eventually (and also suddenly) be judged unwise by the market. ${ }^{27}$

This insight would seem to lead directly to the conclusion that fiscal restraint (and other non-monetary policies) must be the principal tool used to deal with external imbalances if monetary policy is directed to a domestic price objective. Yet it must also be admitted that there remain some uncertainties as to the short-run effects of fiscal restraint in such circumstances. The standard Mundell-Fleming model would say that fiscal restraint would allow lower interest rates and lead to a lower exchange rate in response to capital outflows. The lower exchange rate would lead in turn to foreign demand replacing the previous domestic fiscal stimulus. In this way, the external balance problem would be solved without exacerbating domestic unemployment. In recent years, however, many European policymakers have insisted publicly that fiscal restraint will strengthen the domestic currency (rather than weaken it), and indeed this has been a traditional policy prescription for emerging markets. ${ }^{28}$ Should the latter view be correct, it does raise the issue of how the transition back to full employment would be accomplished. One possibility is that fiscal restraint in an overheating economy might significantly reduce international risk premia, particularly in countries where the domestic finances had previously been thought "out of control". Thus, interest rates could go down enough, crowding in investment and other expenditures, for a depreciation not to be required to restore equilibrium at full employment. $^{29}$ Clearly, in an environment in which fiscal policy was becoming more restrictive and the exchange rate was appreciating at the same time, the monetary authorities would generally be expected to support rather than resist market pressures for lower interest rates.

\subsubsection{Problems of volatile exchange rate expectations}

None of the above complications associated with the operation of a floating exchange rate regime depends crucially on short-term dynamics in exchange rate markets. Such dynamics add yet another layer of complication in a world of highly mobile capital flows. For a start, Dornbusch-type models, anchored in rational expectations, exhibit exchange rate overshooting to monetary shocks. ${ }^{30}$ Beyond this, it is increasingly being suggested that financial markets (both domestic and international) are also

27 The Chancellor of the Exchequer of the United Kingdom, Nigel Lawson, followed a policy of attempting to get sterling to shadow the Deutsche mark in the late 1980s as it strengthened under the influence of German reunification. The subsequent deterioration of the UK trade account was deemed of little importance (the "Lawson doctrine") because the UK fiscal position was strengthening and the external deficit thus had private sector origins. Nevertheless, the pound fell sharply during the European exchange rate crisis of 1992.

28 In Europe, Italy and other countries were urged to cut their deficits (in accordance with the Maastricht Treaty) to help strengthen their currencies in preparation for economic and monetary union. In the recent Asian and Brazilian crises, fiscal restraint was an important part of the recommended policy package to stabilise the currency.

29 While such a process would still leave the country with its initial current account deficit, the implication of a lower risk premium is that it would be easier to finance.

30 Dornbusch (1976) is, of course, the seminal reference. Chapter 9 in Obstfeld and Rogoff (1996) contains a recent overview of Dornbusch-style models. 
prone to "bubble-like" behaviour. ${ }^{31}$ Recent examples would include the US stock market in 1987, the Japanese stock market of the late 1980s and the strength of the Japanese yen in the first half of 1995 . In each instance there was a sharp price movement that was subsequently reversed on the basis of "news" that could not rationally account for such a significant re-evaluation of future prospects for the price of the asset in question. Whether the current valuation of stock prices in many countries, technology (especially internet) stocks in particular, will prove sustainable remains to be determined.

The possibility that internationally integrated markets can generate unwanted pressures in exchange markets also has implications for the conduct of monetary policy. In recent years, many countries with floating exchange rates have begun to monitor an "index of monetary conditions" (MCI), which is a weighted average of short-term interest rates and the exchange rate with weights reflecting the respective effects of each monetary variable on spending. ${ }^{32}$ If imbedded in a forecasting framework that regularly updates the target profile of the MCI, automatic responses of interest rates to offset the effects of movements in the exchange rate (in the period between forecasts) imply a belief that the exchange rate change is not the result of underlying causes that actually require a change in monetary conditions. ${ }^{33}$ This assumption is of course arguable, and may be the reason why the Bank of England and the Reserve Bank of Australia (among others) have chosen not to use the MCI in this way. A further problem arises from the above-noted fact that the transmission mechanism of monetary policy under a floating exchange rate regime is complicated and that the weights required to calculate the MCI are not easy to obtain reliably. ${ }^{34}$ Finally, recognising that long bond rates and asset prices are also part of the transmission mechanism, one might then question (as do many Europeans) why short-term rates should react automatically to exchange rate changes but not to changes in these other variables. One possible answer is that changes to these other variables are more likely to be the product of underlying changes warranting some change in monetary conditions. Thus, it is appropriate to exclude them from the MCI being both monitored and stabilised between forecast dates.

Even in cases where exchange rate pressures do not imply a loss of control over monetary conditions, a sharp movement in the exchange rate offset by movements in interest rates can still cause difficulties. Perhaps the most important point is that higher (lower) prices for traded goods may directly affect aggregate price indices leading to expectations of higher (lower) inflation than is

31 Nor is this a new suggestion. For the liveliest description ever of such processes, see Keynes (1936), Chapter XII.

32 For a discussion of MCIs, see Freedman (1995) and (1994) and Gerlach and Smets (1999).

33 The analytical framework for determining whether unexpected shocks should or should not be met by an automatic policy response was first suggested by Poole (1970). His is a one-period model (akin to the period between forecasts) in which income deviates unexpectedly from an initial and desired position. Since it is not possible in each period to determine the cause of this deviation (a real or a monetary shock?), policymakers must decide where shocks are more likely to originate on average. They then choose to stabilise either the interest rate or the money supply to ensure an appropriate countercyclical response, again on average, in the face of this uncertainty.

34 See Ericsson et al (1997). 
justified by the underlying fundamentals. The danger in the former case is that inflationary pressures may rise. The danger in the latter case is that the monetary authorities may be lulled into a false sense of security, since these disinflationary gains will have to be given up once the currency stabilises or (more likely) reverses. ${ }^{35}$

Another problem with major changes in real exchange rates is that they demand changes in domestic resource allocations which can be costly in themselves and may have important ramifications via the political process. The underlying problem is that overall monetary policy may be excessively influenced by the circumstances of the disadvantaged sector. For example, large depreciations in the United Kingdom, Italy, Finland and Sweden in 1992 first led to a booming tradable goods sector, but with domestic demand remaining everywhere subdued. Internal political pressures directed to easing conditions for the domestic sector had to be resisted to avoid an inflationary bias. More recently, the strong appreciation of sterling has negatively affected the tradable goods sector and it was this group which began to lobby for monetary easing in spite of continuing inflationary tendencies in the wider economy. In Canada, in the early 1970s, similar pressures were not adequately resisted and this contributed to the strong inflation of that period. ${ }^{36}$

As noted above, movements in the exchange rate can in principle be offset by interest rate movements in order to keep the overall level of monetary conditions at the desired level. In practice, however, movements in the exchange rate can generate extrapolative expectations which may prove very difficult to stabilise. Changes in interest rates sufficient to this task could thus imply a loss of control over monetary conditions which, while only temporary, might well last long enough to cause discomfort. Such occurrences have been experienced in Canada on a number of occasions in recent years. ${ }^{37}$ However, it is also worth noting that in virtually every instance the episode was sparked by an attempt to lower short-term interest rates more aggressively than the market thought was warranted. Since interest rates and monetary conditions subsequently had to be sharply tightened, this aggressive easing proved counterproductive.

All of the above has to do with the problems that central banks may face under a floating exchange rate regime. However, various policy measures can be taken by central banks to cope with exchange rate movements of this sort. The first measure must be preventive. Recognising that, in an internationally integrated world, exchange rates reflect expectations of future short rate differentials

35 This could be a current danger in the United States. The extent of this danger would of course depend on how much exchange rate depreciation has contributed to the unexpected weakness of inflation in the United States over the last few years. See BIS (1998b), Table II.5, and Kim (1998).

36 Another problem arising from large shifts in the relative prices of traded and non-traded goods and services is the uncertainties thus generated. Rising unemployment in one sector may so reduce confidence as to slow the economy overall. In such a case, the worry may be more of a disinflationary than an inflationary outcome.

37 For a fuller discussion, see Murray et al (1996). 
over time, stability in the exchange rate will be well served by stability in the conduct of domestic monetary policy. As noted above, an increasing number of central banks are directing monetary policy to the sole objective of price stability and it is also becoming increasingly common for near-term inflation targets to be quantified and publicly announced. Together with increased openness about the use of intermediate targets, and regular explanations concerning changes in the instruments of monetary policy, such transparency should play a useful role in anchoring market expectations. ${ }^{38}$ Ancillary benefits that might also be expected would be lower volatility in both exchange rates and longer-term interest rates, and lower risk spreads relative to major currencies. Prior to events related to the current turmoil in international capital markets, there was indeed emerging evidence of such effects in a number of countries with inflation targeting regimes. For example, in Australia, indicators of rising inflation are now more likely to lead to a rising Australian dollar (rather than to no response as previously) on the new presumption that inflationary pressures will be strongly resisted.

In spite of preventive measures, exchange market pressures may still cause the exchange rate to move too far or too fast. In such circumstances, the monetary authority should normally be prepared to allow interest rates to move sharply to levels likely to stabilise expectations. A failure to do so, particularly if accompanied by major changes in liquidity levels designed to stabilise interest rates instead, could easily generate expectations that the authorities were no longer concerned about the exchange rate. This was clearly part of the problem in Asia, where confidence disappeared suddenly in spite of the fact that many affected countries had a long history of both fiscal and monetary rectitude. ${ }^{39}$ Unfortunately, as described above, prompt action to stabilise expectations may have unpleasant side effects. However, if the only practical alternative is a significant increase in inflation arising from currency depreciation, or the requirement for still greater interest rate swings later to stabilise the currency, these unpleasant side effects may simply have to be accepted.

An interesting complication to such decision-making occurs when countries have issued sovereign liabilities in domestic currency, but with a rate of return indexed to the exchange rate (commonly against the dollar). "Tesobonos" of this sort were issued in Mexico in 1994 and similar instruments now constitute about one-fifth of Brazilian debt as well. While defending the currency with higher interest rates feeds into the fiscal deficit directly, letting the currency slide now also affects the deficit, even if only indirectly via the indexing provisions. ${ }^{40}$ The worst-case scenario is when higher domestic rates fail to stabilise the currency. The "double" effect on the fiscal deficit could then further destabilise exchange rate expectations compounding the crisis. This dilemma for the public sector is

\footnotetext{
38 For a fuller discussion of the role of transparency in the conduct of monetary policy, see BIS (1998b), pp 70-5.

39 The original reluctance of the authorities to take steps to stabilise their currencies contributed materially to the magnitude of the crises. See BIS (1998b), pp 135-7.

40 In the Brazilian case, the short-term effects arising from higher interest rates are larger since the non-indexed debt is of significantly shorter maturity than the indexed debt.
} 
essentially identical to the one described at the top of page 7 (where the private sector was exposed), and leads to the conclusion that indexed instruments of this sort can be dangerous in extremis.

There may be further complications when exchange rate stabilisation implies either very low or very high interest rates. The use of higher interest rates to stabilise a weak currency has no arithmetic limits. Conversely, as was seen in the case of the rising Japanese yen up to 1995 (and currently of concern in the case of the Swiss franc), the fact that interest rates are bounded at zero can be a significant practical constraint in offsetting upward pressures. On the other hand, while low short-term interest rates do not generally pose problems for weak banking systems, high ones directed to supporting the currency commonly do. Problems can arise from inverted yield curves, given that banks normally intermediate from short to long, or from increased bankruptcies associated with higher rates. This has been a significant concern both in Mexico and, more recently, in Asia. Indeed, given the vulnerability of banking systems to credit risk arising directly from market risk and liquidity problems, some commentators have even suggested that higher interest rates may sometimes weaken the currency rather than strengthen it. ${ }^{41}$ Such problems obviously lead to recommendations to reinforce the banking system generally, as is further discussed in Section 3. There may also be merit in temporary efforts to insulate longer-term interest rates from the very short rates used to help defend the currency. France and Sweden both made efforts in this direction during the 1992 crisis, though the relative stability of the French franc indicates the former country did so more successfully.

The use of exchange rate intervention to deal with undesired currency market pressures should also be mentioned. There now seems general agreement that, if intervention works, it does not do so primarily through altering the relative supplies of assets denominated in different currencies (the "portfolio channel"), but rather through the signal it sends that the authorities stand ready to alter more fundamental policies if exchange rate pressure continues (the "signaling channel"). ${ }^{42}$ This consensus would seem to imply that intervention need not be large but should be publicly known and used only intermittently, and that it must be followed up by other policy changes (if need be) to ensure the credibility of future intervention. None of these conditions were met in the case of intervention by most Asian authorities; indeed, intervention was conducted in such a clandestine way (through forward markets) that even the IMF was left unaware of the depleted level of foreign reserves. There

41 Arguments of this sort were heard in Asia early in the crisis, as policymakers tried to explain their reluctance to stabilise the exchange rate.

42 This conclusion formed the basis of the Report of the Working Group on Exchange Market Intervention (see Group of Seven (1983)). Dominguez and Frankel (1993) provide more recent evidence that intervention does not affect exchange rates through the portfolio channel but rather through the signalling channel. Moreover, they find no clear pattern that can help discriminate the effectiveness of coordinated and non-coordinated intervention. Catte et al (1994), however, found that for the yen/dollar and DM/dollar exchange rates during the period 1985-91, coordinated intervention was effective. Humpage (1996) applied a different methodology for the period 1987-91 and found that intervention is more likely to be successful when it is coordinated and heavy. For a survey of the empirical literature on foreign exchange intervention, see Edison (1993). 
is, however, no consensus on the tactical circumstances in which intervention is likely to have its greatest effect. For example, the central banks of some industrial countries feel strongly that intervention is effective only when "leaning with the wind". Others feel that intervention "against the wind" can be effective, particularly if done in large volumes and in a coordinated fashion involving all interested parties.

Finally, all the above points having to do with stabilising currency values are premised on the assumption that the currency of a single country has come under pressure. That is a different situation from the one in which the global economy seemed to find itself in 1998, with a generalised withdrawal from risky assets and risky currencies (emerging markets, "junk" equities, etc.) into the safe haven of liquid assets (primarily government bonds) in large industrial countries. In such circumstances, it would seem a "fallacy of composition" to recommend that a large number of countries simultaneously exercise restrictive policies. Rather, what might be more appropriate is that the beneficiaries of this process should ease their policies to reduce the market pressures on others. While some might interpret this as an inappropriate recommendation to shift the objective of monetary policy away from domestic price stability, it could also be argued that a recommendation of easier policy simply reflects a growing understanding of how a global shift upwards in risk aversion could eventually have disinflationary implications for the industrial countries themselves. This issue is returned to in Section 3.2.

\subsection{Squaring the circle with capital controls?}

It would seem that internationally integrated capital markets pose challenges to the maintenance of domestic price stability, whether central bankers are operating under a fixed or a flexible exchange rate regime. While central banks have means to alleviate these problems, they are not in a position to eliminate them. What would help significantly, to reduce both unwanted exchange rate volatility and longer-term misalignments, would be sustainable fiscal policies (needed in Brazil) as well as political stability (needed in Malaysia and Indonesia). However, these advantages are not everywhere available. What would also help to reduce the macroeconomic implications of international capital flows would be healthier domestic financial systems. Again (see Section 3), most emerging market countries do not currently pass this test and, realistically, it will take them many years to do so. ${ }^{43}$

In these circumstances, increasing attention is being directed to devices to impede the international flow of capital to emerging markets. ${ }^{44}$ Indeed, a number of countries have already taken concrete steps

\footnotetext{
43 What is also implicit in this observation is that it can be dangerous to liberalise the capital account before certain domestic prerequisites are put in place.

44 For recent surveys of capital controls, see Dooley (1997) and (1996) and Grilli and Milesi-Ferretti (1995). Chile's much discussed system of controls is discussed in IMF (1998).
} 
in this direction: Chile, Malaysia, China and Russia among others. These steps go far beyond earlier calls for a more prudent dismantling of earlier controls, extending in the Russian case to what is effectively a debt default and a prospect of non-convertibility. To date at least, perhaps for the reasons suggested in Section 1, no one has recommended such action in any industrial country. It is obviously tempting for individual countries in desperate circumstances to emphasise the short-run advantages of controls over their longer-run disadvantages. Among the former, one must include the possibility of easing monetary and fiscal policies (in the face of domestic deflation) without unwanted effects on the exchange rate. Reducing the potential damage caused by excessive inflows and then precipitate outflows, particularly via weak and exposed domestic banking systems, also has its attractions. Among the disadvantages for individual countries would be a worsened international allocation of capital, the fact that controls become increasingly porous with time, and the high probability that controls will be subject to bureaucratic abuse and even corruption. It is also the case that controls can have perverse effects; for example, restrictions on outflows will clearly reduce the potential for inflows.

If capital controls are to be imposed in an individual country, there seems to be a growing consensus on how this should be done. It should be clear from the first that the controls are temporary and the criteria for their removal should be stated in advance. Controls on inflows are much to be preferred over controls on outflows. Moreover, controls on inflows should focus on shorter-term portfolio investments rather than foreign direct investment. Where there is no consensus is on how to manage the international ramifications of individual countries resorting unilaterally to controls, particularly of outflows. The greatest danger is that international investors observe individual countries going down this restrictive path and presume that others will follow. To add a new concern about transfer risk to already heightened concerns about credit, market and liquidity risk could threaten a wholesale withdrawal from emerging markets regardless of the circumstances of individual countries. Such externalities would seem to warrant severe international censure for countries taking unilateral measures likely to generate such concerns.

\section{Implications for policies directed to financial stability}

Before turning to the complications arising from international financial integration, it is worth considering the role played by central banks in helping to ensure domestic financial stability. Anecdotal and survey evidence indicates that most central banks in countries with well-developed financial systems feel that they have a significant responsibility for ensuring domestic financial stability, even if the precise meaning of this mandate remains somewhat elusive. Indeed, in such countries as the United Kingdom and Australia, where responsibility for the supervision of financial institutions has recently been given to a separate agency outside the central bank, this overall 
responsibility for financial stability has been formalised in legislation. ${ }^{45}$ In most countries, central banks are now devoting far more resources to the issue of financial stability than was the case 20 years ago. The fundamental reason for this has been the growth of liberalised financial markets, responding to both technological developments and the search for efficiency, and the associated increase in the risk of financial instability. ${ }^{46}$ In recent years, financial crises have erupted with increasing regularity in both industrial and emerging markets, indicating that the concerns of central bankers in this area are fully justified even if their endeavours have not yet been wholly successful.

In response to these challenges, a great deal of work has gone into identifying the sources of financial instability and possible preventive measures. A useful organising framework for thought is a fourdimensional matrix, taking the form of an augmented flow-of-funds table. ${ }^{47}$ As in the standard flow of funds, one dimension distinguishes between the various market participants (banks, securities dealers, mutual funds, governments, etc.) while the second records the various financial markets (government securities, bank loans, derivatives, etc.). The third dimension is the underlying market infrastructure (legal framework, clearing and payment systems). And the fourth dimension is the market clearing conditions through which demand equals supply in all markets simultaneously. Failures or disruptions at the level of the first three dimensions will have effects on these market clearing conditions (interest rates, exchange rates, asset prices, etc.), which will in turn affect the real economy with attendant effects on output, unemployment and inflation. It is in this sense that financial stability and monetary stability are said to be two sides of the same coin. Needless to say, the causation can also be reversed with macroeconomic instability leading to financial instability, commonly via credit and asset price bubbles.

Recognising these interdependencies, central banks can take measures at both the micro and the macro levels to foster financial stability. Underpinning all these policies, whether at the micro or macro levels, is the recognition that market processes are increasingly the dominant force in financial markets. The implication of this fundamental insight is that public policies should be primarily directed to redressing market failures, and that such policies should rely on market-compatible incentives to prudent financial behaviour. ${ }^{48}$ The fact that markets are increasingly international also has policy implications which is the focus of attention below.

45

In the United Kingdom a decision was quickly reached by the new Labour government to consolidate all supervision of financial institutions and markets in the hands of one agency, the Financial Supervisory Authority. In Australia a similar decision was made to establish the Australian Prudential Regulation Authority, but only after an extensive study on the issue by the "Wallis Group". For a seminal article on the growing reliance on market processes and the implications for central banks, see Padoa-Schioppa and Saccomanni (1994).

47 See White (1994).

48 As an example of this, consider the increasing reliance by banking supervisors on firms' own internal models to calculate capital requirements for market risk. Similar interest is being shown in using internal credit risk models, although thinking here is less well advanced. 


\subsection{Micro policies to foster financial stability}

Micro measures to promote financial stability involve regulation and oversight of individual parts of the system with a view to influencing behaviour or gathering information which can be of use either in preventing crises or managing them better. ${ }^{49}$ At the micro level, policies to foster financial stability have focused on each of the three pillars supporting the international financial system: institutions, markets and infrastructure. The overriding objective is a "systemic" one, to ensure that whatever the source of disturbance might be, it does not feed through to exacerbate weaknesses elsewhere in the system with possibly non-linear effects. Thus, central banks (often in association with other bodies) can play a regulatory or supervisory role with respect to financial institutions, conduct market surveillance, and oversee the functioning of payment and settlement systems. This comprehensive approach to crisis prevention might be contrasted with one in which a particular "disaster scenario" is laid out and specific steps taken to ensure it does not happen. The problem with the latter approach is that it assumes such scenarios can be identified ex ante. The reality is that they cannot since, in the real world, big problems are much more likely to be caused by the unforeseeable accumulation and interaction of a number of small problems than by some single calamitous event.

\subsubsection{Issues of process}

International financial integration has profound implications for the process through which central banks and other national authorities develop micro policies to foster financial stability. The reality is that each of the three dimensions just referred to has become internationalised. Banks and other financial institutions now compete in many different countries, implying the need for international agreements to ensure a regulatory "level playing-field". ${ }^{50}$ Moreover, the national participation in forging such agreements must be widespread enough to avoid the possibility of regulatory arbitrage (a migration of business to non-participating countries) and to ensure a sense of ownership on the part of both industrial and emerging market authorities likely to be affected by the agreements. As noted above, markets are also becoming increasingly international. Shocks which occur in one country can now be easily transmitted to other countries. While this can sometimes be useful, if the final effect is to dilute the impact of shocks in a harmless manner, it is equally possible that they may lead to

49 In countries where central banks do not regulate or supervise the banking system, the information and influence provided by this function also disappear. One possible response on the part of central banks is to use their other functions, including the conduct of monetary policy, to try to redress any resulting shortcomings of either information or influence. Failing this, another approach might be for central banks in this position to point out that they no longer have the tools to carry out a mandate for maintaining financial stability. At the least (and this could even apply to banks with supervisory responsibilities) it should be noted that other government agencies share the responsibility for financial stability.

50

By the same token, traditional sectoral distinctions between banks, investment dealers and insurance companies are also breaking down, implying the need for a level playing-field across sectors and for more comprehensive oversight of international financial conglomerates. See BIS: BCBS (1998) and Group of Thirty (1997). 
contagion or gridlock in markets where nothing fundamental has changed to justify such an outcome. ${ }^{51}$ In such circumstances, central banks and others would benefit from an international exchange of information leading to action aimed at either preventing or containing a crisis. And finally, with a large and growing proportion of payments now involving counterparties of different nationalities, failures of payment systems in one country will have immediate effects on other countries. Recognition of all these interdependencies implies that the scope for unilateral efforts to strengthen national financial systems is now very much constrained.

As a result of these changing circumstances, international meetings of central banks and other regulators have expanded enormously in recent years. Since most of these meetings take place at the BIS, the need for secretariat support work supplied by that institution has also increased commensurately. ${ }^{52}$ There is in fact a G10 committee of national experts directed to each of the three dimensions of the international financial system referred to above. First, the Basle Committee on Banking Supervision (BCBS) focuses on the health of banks and is increasingly interacting with the international regulators of investment dealers (IOSCO, with its Secretariat in Montreal) and insurance companies (the IAIS, now also resident in Basle) under the aegis of the Joint Forum. Second, the Committee on the Global Financial System (CGFS; formerly named the Euro-currency Standing Committee) has for many years monitored and analysed major developments in financial markets and their possible implications for financial stability. Finally, the Committee on Payment and Settlement Systems (CPSS) monitors developments in this increasingly important area of financial infrastructure. ${ }^{53}$ All three standing committees have in recent years published numerous studies, many with specific recommendations as to how national legislation, regulation and practices might be amended to help foster both national and international financial stability. The important point to note is that, while final decisions must still be taken at the national level where sovereignty continues to reside, these national decisions are increasingly the final act in a long process of international negotiation and agreement among national experts meeting in Basle and elsewhere. Therefore, while national sovereignty remains in an internationally integrated financial world, it does so in a form that is materially constrained. ${ }^{54}$

51 See White (1998a).

52 See White (1998b).

53 While there is no standing committee directed to problems arising in the international legal infrastructure, this important area is attracting increasing attention. In particular, the absence of adequate national bankruptcy procedures in some cases (e.g. recently in Asia) and international disputes about the interpretation of existing laws (e.g. around the failure of BCCI) can cause significant problems.

54 Kapstein (1994) and (1992) provides the perspective of a political scientist in assessing the preconditions required to make the "Basle process" (as he calls it) work effectively. 


\subsubsection{Issues of substance}

It must be admitted that many of the major initiatives taken by these BIS standing committees over the years have been byproducts of past financial crises rather than forward-looking efforts to avoid difficulties. Indeed, this pattern can be seen again in (at least) three sets of issues raised by the recent Mexican (1994) and East Asian crises (1997). The first crisis led to a greater appreciation of the need to set international standards of best practices in general. The latter crisis has led to a recognition of the particular need for transparency on the part of all economic agents if international financial markets are to function effectively. Finally, and likely a byproduct of both crises, there is a growing if still inadequate recognition that agreement on proper standards (including levels of transparency) must be followed up by ensuring their proper implementation on a global scale. Each of these issues is considered in turn below.

The Mexican crisis had its roots in a weak domestic banking system and an unhealthy degree of reliance on foreign capital inflows. As it became increasingly recognised that other emerging economies were likely to face similar institutional weaknesses, international pressure began to build for the formulation of a set of "Core Principles for Effective Banking Supervision". The BCBS drafted such principles, ${ }^{55}$ with the cooperation of a large number of non-G10 central banks and other supervisory agencies, and is now advocating their adoption through various international fora. As experience with the international application of the Core Principles accumulates, they will be revised and clarified with a view to making them more useful in industrial and emerging market countries alike. Moreover, this concept of internationally applicable "Core Principles" or "Standards of Best Practice" now appears to be spreading rapidly, with IOSCO and the IAIS having already issued such standards. The CPSS is now working on a set of Core Principles in its area of expertise as well.

Going beyond the realm of central bankers and supervisors, others interested in international financial stability are also supporting the idea of international standards set cooperatively by committees made up of national experts. In a recent (1997) study on ways to strengthen financial structures in emerging markets, central bank and Treasury officials from many countries strongly recommended this approach. ${ }^{56}$ Not only did they make reference to areas where such standards were clearly required, but they also suggested a number of other areas where the possibility of such standards should be further investigated. Following up on this suggestion, the G10 Governors subsequently asked the three Baslebased committees to consider nine separate areas (transparency, use of information, safety nets, dealing with weak institutions, corporate governance, market access, legal framework, deep and liquid markets) where such standards might be both desirable and feasible. In addition, the committees were asked to recommend which group of national experts might be best placed to develop such standards.

55 See BIS: BCBS (1999c) and (1997). 
This work is advancing and was an important component of the contributions made by the Basle community to the ongoing work of the Willard Group and its three sub-groups. ${ }^{57}$ The recently released reports of these three sub-groups contain a number of explicit recommendations to promote international financial stability.

Another belief that has grown in strength in light of recent crises is that increased transparency on the part of all economic agents would sharply improve the functioning of international markets and lead to greater financial stability. ${ }^{58}$ It is difficult to object to this at the level of principle, though it is disconcerting that much of the impetus for this belief comes from a misapprehension. It has been frequently asserted that the size of the capital inflows into the Asian countries later affected by the crisis would have been much smaller had the individual investors been made aware of the aggregate exposure of these countries. It is hard to believe that the basic problem was a shortage of information given that the international financial statistics collected semiannually by the BIS and the OECD (based on banking statistics and trade credits) were widely available. These data clearly indicated both growing debt levels and a very high proportion of short-term debt in the case of many countries. Indeed, concerns based on these international banking figures (albeit sotto voce) were raised as far back as 1995 in the quarterly publications of the BIS as well as in successive BIS Annual Reports. ${ }^{59}$

Yet it must also be admitted that data pertaining to the behaviour of non-banks during the Asian crisis were very limited. This shortcoming has already led to a number of initiatives. With respect to the public sector, the CGFS has developed a template for revealing national foreign exchange reserves (and contingent claims against them) in a more transparent way. This template, which will be part of the IMF's SDDS database, was a response to the misleading information provided to the markets and the IMF by governments in a number of Asian countries involved in the crisis. ${ }^{60}$ What also seems to have been agreed in the international central banking community is that it would be desirable to have

56 See Group of Ten (1997).

57 For a summary of these reports, see BIS/IMF/OECD/World Bank (1998a).

58 See BIS/IMF/OECD/World Bank (1998b) and also BIS (1997), Chapter IV.

59 To say that a lack of information was not the heart of the problem is not to say that the available figures were ideal. Indeed, after the Mexican crisis, the (then) Euro-currency Standing Committee made considerable efforts to improve the semiannual banking statistics collected by the BIS. Steps were taken to expand the number of reporting countries and the reporting and publication lags were reduced from more than six to less than five months and still further reductions are planned. As well, steps were taken to reclassify the exposure of national banking systems on the basis of "ultimate risk" to deal with the problem of loans booked by emerging market countries in international financial centres. In another development, the Inter-Agency Task Force on Finance Statistics has agreed to build on and replace an existing set of BIS/OECD external debt statistics with a new set of debt statistics which is jointly issued by the BIS, IMF, OECD and World Bank. It brings together for the first time the best international comparative data currently available on external debt. These data are now being published quarterly.

One feature of the Asian crisis was that a number of governments supported their currencies extensively using forwards and other forms of off-balance sheet intervention. This information was hidden from the public and, when revealed, indicated that the true level of reserves was much less than thought. This contributed to the aura of panic and the sudden desire on the part of creditors to withdraw. To provide an example of proper behaviour in this regard, the G10 countries agreed to adhere to the template drawn up by the CGFS. 
more information about the activities of highly leveraged investors who are internationally active. Currently, three avenues are being actively explored within the Basle community. ${ }^{61}$

A third issue raised by these recent crises has to do with turning principles of good behaviour in the financial sector into good practices. What forms of international pressure can be exerted to foster the implementation of such principles? In the area of banking supervision, where thinking is more advanced than in other areas, four complementary sets of processes look promising: an international code of transparency for national supervisors; international peer pressure; tightened residency requirements; and market discipline. The first three of these provide incentives for national supervisors to enforce the Core Principles. The fourth provides incentives for owners and managers of banks to act in accordance with these Principles. While the specifics of the processes pertain to implementation of best practice in the area of banking supervision, similar incentives might be applicable in other areas as well.

The first process directed to ensuring implementation of the Core Principles of Banking Supervision has been the preparation of another code - namely, a "Code of Good Practices in Transparency in Monetary and Financial Policies". This Code, which is being put together by the IMF in association with the BIS and relevant international committees of regulators, deals in part with the need for transparency in the formulation and conduct of all policies (deemed financial policies) having implications for financial stability. If information about how the supervisors are behaving is a necessary but not sufficient condition for ensuring that the banks are behaving properly, this Code of Transparency seems a useful initiative. The Code of Transparency is still in the process of being finalised, but in its current form it is based upon a sensible if (to some) radical framework. Akin to what is increasingly being accepted in the realm of monetary policy, the draft Code suggests there should be transparency with respect to the supervisors' mandate, the effectiveness of their powers, and their democratic accountability to other bodies. In effect, this Code of Transparency tries to ensure that the supervisors do their job in implementing the Core Principles.

While transparency may be a necessary condition to ensure that supervisors carry out effectively their task of implementing the Core Principles, it is clearly not sufficient. ${ }^{62}$ While the IMF will be

61 The Basle Supervisors are primarily concerned about the health of banks and wish to be assured that the loans made to highly leveraged institutions are subject to the proper kind of credit analysis. A sub-group of the BCBS (the Brockmeijer working group) has already published two documents, one outlining deficiencies in past banking practices (see BIS: BCBS (1999a)) and the other suggesting guidelines for good practice in the future (see BIS: BCBS (1999b)). The CGFS has two initiatives under way. One is a reprise (under the same chairman) of the 1994 Fisher Report (see BIS: ECSC (1994)), which acted as a catalyst for enhancements to disclosure practices by financial institutions in relation to their exposures to market and credit risks, including those arising from their off-balance sheet activities. The primary objective of this exercise is to encourage further improvements in disclosure so as to ensure that market participants have an adequate basis for an appreciation of the risks they are running in dealing with counterparties. The second CGFS initiative is to examine what kind of aggregate information about the positions of highly leveraged investors would help to improve the functioning of markets and what the disadvantages of such an exercise might be.

62 While the focus of this paper is on international forms of pressure to encourage proper supervisory practices, some domestic issues cannot be overlooked. Supervisors must be paid adequately to prevent a constant haemorrhaging of staff 
monitoring compliance with the Code of Transparency (and also the implementation of the Core Principles themselves ${ }^{63}$ ), the influence the IMF can exert may be relatively limited unless the country in question has an active programme with the IMF. One complementary suggestion that might be helpful is the exercise of international "peer pressure" on national supervisors. Indeed, given that effective banking supervision is often resisted by the political authorities (because of connected lending and other reasons), Central Bank Governors and Finance Ministers from developed countries might usefully try to put similar pressure on their counterparts in emerging markets. ${ }^{64}$ In a similar if more extreme vein, a third suggestion would be to limit more tightly the "right of establishment" in the world's major financial centres. In effect, banks without an adequate supervisory framework in their own country would not be able to conduct an international banking business. This may seem radical, but has been a dictum among industrial countries since the 1975 Basle Concordat. ${ }^{65}$

The fourth set of incentives applies to the owners and managers of banks. Aside from effective supervisory pressure, how can they be induced to behave in ways which are consistent with appropriate corporate governance and effective risk management? The first and most obvious point is that they should suffer in light of inappropriate behaviour. This implies that the owners should have their own capital at stake and that managers should be treated as the stewards of that capital. What is also increasingly needed is for market discipline to be used to get the attention of owners and managers. Moreover, markets are increasingly international and reflect the analysis and judgements of internationally active rating agencies. Financial institutions which are thought to be badly managed, or willing to take excessive risks, should have to pay a market price for this; funds should be available only at a premium; collateral requirements should be onerous and share prices be marked down. Moreover, a similar price should be exacted from firms which release too little information to allow judgements to be made in this regard. ${ }^{66}$ Central banks, and other authorities interested in promoting financial stability through their own activities, should welcome the complementary discipline exercised by international markets in this regard.

to the private financial sector. Other working conditions must be suitably attractive, including personal legal protection from litigation arising from official decisions. And lastly, supervisors must be properly trained and their training continuously updated to reflect new circumstances created by a changing financial world. The establishment at the BIS of the Financial Stability Institute will go a small way to helping in this last regard. However, the personnel challenge is huge and many years of intensive efforts will be required to respond to it adequately.

63 It is possible that the IMF and World Bank will also play a role in implementing "Codes" elaborated by other Basle-based committees.

64 Financial stability in emerging market economies by the Group of Ten (see Group of Ten (1997)) contained a number of practical recommendations as to how financial stability might be promoted. A meeting of Central Bank Governors and Finance Ministers from both industrial and emerging markets took place in Hong Kong in October 1997 with a view to exerting pressure of this sort. Sadly, most industrial countries were represented only by lower-level officials.

65 See BIS: BCBS (1975).

66 This is also a rationale behind, for instance, the Disclosure framework for securities settlement systems by the CPSS and IOSCO (see BIS: CPSS (1997)). 


\subsection{Macro policies to foster financial stability}

Macro measures conducted by central banks traditionally include the provision of liquidity to the system through an expansion of the balance sheet of the central bank. However, as the interdependencies between macro stability and financial stability have become better recognised, two other considerations have more recently come to the fore. One issue is the extent to which concerns about financial fragility should influence the conduct of monetary policy and the pursuit of domestic price (CPI) stability. The second issue is whether prudential norms should be designed and implemented so as to reflect their potential macroeconomic implications.

A traditional role of central banks is to provide adequate domestic liquidity through the lender of last resort function. As financial markets have become increasingly interdependent, and different kinds of financial institutions have entered into alliances of various sorts, it has become harder to balance off short-term exigencies against the longer-term need to reduce moral hazard and to limit the application of the social safety net. The fact that domestic financial markets are increasingly subject to international influences further complicates the task of the central bank in at least two ways.

It is increasingly likely that the financial institution requiring liquidity support will be incorporated and supervised in some foreign jurisdiction. While it might be thought that the "home" central bank should provide the first line of liquidity support, since the "home" regulator is primarily responsible for prudential supervision, the possibility remains that the "host" central bank will be drawn into the affair. The provision of credit will, however, depend on a determination that the affected bank is illiquid rather than insolvent. This is always a difficult distinction, and is likely to be made even more uncertain in the case of a financial institution registered and supervised in a different national jurisdiction. A further problem with internationally active institutions (including domestic ones) is that the liquidity support needed may be in a foreign currency. While the central bank may have adequate foreign reserves to meet such requirements, this need not be the case. In raising the required foreign funds, the central bank will clearly have to pay attention to the potential impact on the exchange rate and the stance of monetary policy more generally.

A current question of interest to central banks concerned about financial stability is the extent to which such concerns should condition the conduct of domestic monetary policy, and what the international implications of such actions might be. One unfortunate possibility is that such concerns might lead inadvertently to a more inflationary domestic outturn. Indeed, possibilities of this sort may have contributed to the decision taken to maintain responsibility for banking supervision at the national level in Europe, rather than to give that responsibility to the European Central Bank. Concerns have also been expressed that highly expansionary monetary policies, aimed in part at easing domestic financial distress, could lead to sharp currency depreciation and the transfer of these disinflationary pressures to other countries which might or might not welcome them. While various factors were at 
work in both instances, the sharp depreciation of the US dollar in the early 1990s (which contributed to an unwelcome tightening of monetary conditions in Japan) and the equally sharp depreciation of the yen subsequently (which had a more welcome disinflationary impact in the United States) could be interpreted as examples of this genre. Finally, it has also been suggested that expansionary monetary policies, geared in part to supporting domestic financial institutions, might contribute to asset price bubbles in other countries. The availability of low-cost funding in the United States (along with the associated decline in the value of currencies pegged to the dollar) is likely to have contributed to the strength of the boom in Asia in the early 1990s, while more recently the "yen carry" transactions may have helped support US asset prices.

Despite these possible complications, there are circumstances in which short-term concerns about financial stability might seem to call for monetary easing. The decision to reduce interest rates in the United States in the fall of 1998 was taken in part to reduce fears of financial instability at that time. A combination of the Russian debt default and the subsequent difficulties faced by Long-Term Capital Management led to a flight to liquidity, a sharp widening of credit and liquidity spreads (particularly in the United States) and a sudden drying-up of capital flows to many emerging markets. While the response of the Federal Reserve was motivated primarily by concerns about the ultimate implications for aggregate domestic demand and inflation in the United States, there can be little doubt that the decision to ease policy had both international roots and international implications. The fact that policy rates were eased, in spite of concerns that US equity markets at the time might already be overvalued, gives further weight to the view that concerns about short-term financial instability played a significant role in the Fed's decision. The subsequent sharp increase in equity prices, not only in the United States but elsewhere, indicates a further complication to the conduct of monetary policy in such circumstances. Should such equity price increases raise the likelihood of a sharp reversal of such movements later, the cost of less financial instability today could possibly be more instability in the future.

A final set of macro policy issues arises from the fact that both the design and the implementation of prudential policies may have macroeconomic implications. With respect to the design of policies, the details of regulatory capital ratios could induce forms of behaviour with potential macroeconomic implications. ${ }^{67}$ For example, it has been suggested that the ability of the Japanese banks to include a significant proportion of their unrealised capital gains on property and equity in their regulatory capital gave them an added incentive to make further loans which fuelled the asset price bubble of the late 1980s. More recently, it has been suggested that some detailed specifications of the regulatory capital ratios may have encouraged excessive short-term interbank inflows into East Asia.

67 The role that capital ratios might play in encouraging and restraining lending was first noted by Gurley and Shaw (1960), pp 280-91. 
These possibilities deserve to be examined more carefully. ${ }^{68}$ Broadly speaking, if prudential policies can be shown to have macroeconomic implications (at either the domestic or international level) through the conduit of credit and asset price cycles, then central banks and other macroeconomic policymakers might be interested in their design. At the very least, one would hope that any identified procyclical forces generated by prudential policies might be removed. It would, however, be a much more ambitious conclusion to recommend that prudential policies might actually be used to help reduce cyclical fluctuations. ${ }^{69}$ The idea of regulatory capital requirements which rise in good times and fall in bad might (or might not) have some appeal at the domestic level. However, it is not at all clear how regulatory arbitrage between different countries at different stages of the business cycle might be avoided. Again, the international dimension provides a further challenge to the thinking of those concerned with financial stability.

The implementation of prudential policies could also have some macroeconomic implications. Consider a case in which large parts of the banking system were pressing up against minimum capital ratios in a weak macroeconomic environment. Regulatory efforts to ensure maintenance of minimum standards could easily lead to generalised credit rationing which would exacerbate the economic downturn. In effect, forcing a large number of banks simultaneously to behave in a way that would be eminently suitable for a single bank could be another example of the "fallacy of composition". Central banks and others concerned with macroeconomic policies might play a useful role in identifying problems of this sort. The obvious response to such circumstances is that the banking system should be restructured and recapitalised. However, should this not be possible for political or other reasons, consideration might have to be given to other ways to avoid or to offset credit rationing of the sort hypothesised. Given the desirability of an international "level playing-field", some such decisions might have to be internationally negotiated.

\section{Conclusions}

International financial markets are now integrated to a remarkable degree. Whereas the size of international capital flows (relative to levels of output) was certainly higher prior to the First World War, the short-term nature, high turnover and multiplicity of agents which characterise international financial markets today are unprecedented. ${ }^{70}$ This evolution has been actively encouraged by many academics and public policymakers. In addition to an improved international allocation of capital,

68

The BCBS hopes to issue a consultation document in April 1999 with a view to revising earlier international agreements with respect to regulatory capital.

69 Some policies of this kind have already been put in place in Hong Kong and Singapore. In both jurisdictions, the proportion of property values that can be used as collateral for loans declines as the price of the asset rises.

70 See Bordo et al (1998). 
internationally integrated markets have been thought to provide a discipline to domestic policymakers that would be both measured and welcome. This consensus has, however, come under closer scrutiny in recent years in the light of a number of troubling developments.

Some of the difficulties posed by highly mobile capital flows for the conduct of monetary policy became quite evident during the 1992 crisis in the ERM, the Mexican and Asian crises and various periods of exchange rate instability in Canada and elsewhere. Perhaps the broad conclusion to be drawn is that exchange rate pressures can be managed and crisis avoided, but only if the underlying financial structure is robust and the fiscal position of the country concerned is supportive of the credibility of the monetary authority. The monetary authority must itself also show a willingness to respond vigorously to such pressures, even if it may sometimes prove domestically inconvenient to do so. In many emerging market countries, a greater reliance on managed floating might have helped avoid the worst of the problems associated with the rapid inflow and outflow of foreign capital.

As for the possible implications of highly integrated financial markets for financial stability, the Mexican and even more recent experiences in Asia also raise serious issues. Shared domestic problems, in particular excessive capital formation and asset price bubbles fuelled by domestic credit expansion, were at the root of the Asian problem. Yet there now seems little doubt that foreign capital inflows seriously compounded Asian difficulties. A sudden turnaround in sentiment on the part of foreign bank lenders also caused problems, even though it can be argued that in some countries domestic capital flight began first. ${ }^{71}$ At a still more fundamental level, investors in international financial markets have for a number of years sought out high rates of return with very little attention to associated risks. ${ }^{72}$ This process now seems finally to have gone into reverse, with the Russian debt moratorium in August 1998 having definitively changed the rules of the game for many investors who expected to ultimately receive public sector support. This development was met with sharply rising credit spreads and liquidity premia in many markets and a general withdrawal of funds from all markets thought to be relatively risky. While markets subsequently stabilised, it was still unclear by early 1999 whether all of the implications of this unwinding of positions had been felt.

As noted in this paper, a great deal of progress has already been made in strengthening the central pillars of the international financial system: institutions, markets and infrastructure. What is also clear is that further progress remains to be made in implementing internationally many practices already recognised as being desirable. Perhaps of even greater concern, there are still many areas (particularly

71 Evidence that hedge funds precipitated the crises in various Asian markets is generally anecdotal, other than in the case of Hong Kong. For some empirical evidence downplaying the role of hedge funds, see BIS (1998b), Chapter V. Nevertheless, efforts are now under way under the aegis of both the BCBS and the CGFS to throw more light on the activities of highly leveraged investment funds of this sort. See BIS: BCBS (1999a) and (1999b).

72 Concerns about this tendency have been expressed in successive BIS Annual Reports: see BIS (1995a), p 3, and BIS (1996b), p 4, for early references. 
the nexus between prudential policies and macroeconomic variables of interest) where desirable policies have not yet been identified, much less implemented. Many years of effort, both at the domestic and at international levels, will be required on the part of central bankers as well as many others to ensure that the international financial system demonstrates the proper balance between efficiency and stability. 


\section{References}

Bank for International Settlements (1998a): International banking and financial market developments, November.

Bank for International Settlements (1998b): 68th Annual Report, June.

Bank for International Settlements (1998c): "The role of asset prices in the formulation of monetary policy". BIS Conference Papers No 5, March.

Bank for International Settlements (1997): 67th Annual Report, June.

Bank for International Settlements (1996a): "Changing financial systems in small open economies". BIS Policy Papers No 1, December.

Bank for International Settlements (1996b): 66th Annual Report, June.

Bank for International Settlements (1995a): 65th Annual Report, June.

Bank for International Settlements (1995b): "Financial structure and the monetary policy transmission mechanism". CB Document No 394, March.

Bank for International Settlements: Basle Committee on Banking Supervision (1999a): Banks' interactions with highly leveraged institutions, January.

Bank for International Settlements: Basle Committee on Banking Supervision (1999b): Sound practices for banks' interactions with highly leveraged institutions, January.

Bank for International Settlements: Basle Committee on Banking Supervision (1999c): Compendium of documents produced by the Basle Committee on Banking Supervision, January.

Bank for International Settlements: Basle Committee on Banking Supervision (1998): Supervision of financial conglomerates. Papers prepared by the Joint Forum on Financial Conglomerates, Bank for International Settlements, January.

Bank for International Settlements: Basle Committee on Banking Supervision (1997): Core principles for effective banking supervision, September.

Bank for International Settlements: Basle Committee on Banking Supervision (1975): Report on the supervision of banks' foreign establishments.

Bank for International Settlements: Committee on Payment and Settlement Systems (1998): Statistics on payment systems in the Group of Ten countries, December.

Bank for International Settlements: Committee on Payment and Settlement Systems (1997): Disclosure framework for securities settlement systems, February.

Bank for International Settlements: Euro-currency Standing Committee (1994): A discussion paper on public disclosure of market and credit risks by financial intermediaries (Fisher Report), September.

BIS/IMF/OECD/World Bank (1998a): Summary of reports on the international financial architecture, October.

BIS/IMF/OECD/World Bank (1998b): Report of The Working Group on Transparency and Accountability, October.

Barro, Robert J (1995): “Inflation and economic growth". Bank of England Quarterly Bulletin, May, pp 166-76.

Berg, Claes and Lars Jonung (1998): "Pioneering price level targeting: the Swedish experience 1931-37”. Sveriges Riksbank Working Paper Series, No 63.

Bernanke, Ben S, Thomas Laubach, Fredric S Mishkin and Adam S Posen (1998): Inflation targeting. Princeton, NJ: Princeton University Press. 
Bordo, Michael D, Barry Eichengreen and Jongwoo Kim (1998): "Was there really an earlier period of international financial integration comparable to today?" NBER Working Paper No 6738, September.

Bruno, Michael and William Easterly (1995): "Inflation crises and long-run growth". NBER Working Paper, No 5209.

Catte, Pietro, Giampaolo Galli and Salvatore Rebecchini (1994): "Concerted interventions and the dollar: an analysis of daily data", in Kenen, Papadia and Saccomanni (eds), The international monetary system. Cambridge: Cambridge University Press.

Cochran, John P and Fred R Glahe (1999): The drama: the Hayek-Keynes debate over the nature and causes of the business cycle. Lewiston, New York: Edwin Melton Press (forthcoming).

de Gregorio, José (1996): "Inflation, growth and central banks". World Bank Policy Research Working Paper, No 1575.

Dominguez, Kathryn and Jeffrey Frankel (1993): Does foreign exchange intervention work? Washington: Institute for International Economics.

Dooley, Michael (1997): "Capital controls and emerging markets". International Journal of Finance and Economics, Vol 1, pp 197-205.

Dooley, Michael (1996): “A survey of literature on controls over international capital transactions". IMF Staff Papers, Vol 43, pp 639-87.

Dornbusch, Rüdiger (1976): "Expectations and exchange rate dynamics". Journal of Political Economy, Vol 84, pp 1161-76.

Edison, Hali (1993): "The effectiveness of central bank intervention: a survey of the literature after 1982”. Special Papers in International Economics, No 18, Princeton University.

Ericsson, Neil R, Eilev S Jansen, Neva A Kerbeshian and Ragnar Nymoen (1997): "Understanding a monetary conditions index". Unpublished working paper, Federal Reserve Board.

Fischer, Stanley (1993): "The role of macroeconomic factors in growth". Journal of Monetary Economics, Vol 32, pp 485-512.

Freedman, Charles (1995): "The role of monetary conditions and the monetary conditions index in the conduct of policy". Bank of Canada Review, Autumn, pp 53-9.

Freedman, Charles (1994): "The use of indicators and monetary conditions index in Canada", in T J T Balino and C Cottarelli (eds), Frameworks for monetary stability - policy issues and country experiences. Washington: International Monetary Fund.

Galati, Gabriele (1998): "The role of major currencies in emerging foreign exchange markets". International banking and financial market developments, Bank for International Settlements, February, pp 34-7.

Gerlach, Stefan and Frank Smets (1999): "MCIs and monetary policy". European Economic Review (forthcoming).

Goldstein, Morris and Philip Turner (1996): "Banking crises in emerging economies: origins and policy options". BIS Economic Papers No 46, October.

Grilli, Vittorio and Gian Maria Milesi-Ferretti (1995): "Economic effects and structural determinants of capital controls". IMF Staff Papers, Vol 42, pp 517-51.

Group of Seven (1983): Report of the Working Group on Exchange Market Intervention (Jurgensen Report). Washington, January.

Group of Ten (1997): Financial stability in emerging market economies: a strategy for the formulation, adoption and implementation of sound principles and practices to strengthen financial systems. Bank for International Settlements, April. 
Group of Thirty (1997): Global institutions, national supervision and systemic risk: a Study Group report. Washington.

Gurley, John G and Edward S Shaw (1960): Money in a theory of finance. Washington: The Brookings Institution.

Hanke, Steve H, Lars Jonung and Kurt Schuler (1993): Russian currency and finance. London: Routledge.

Humpage, Owen (1996): "US intervention: assessing the probability of success". Federal Reserve Bank of Cleveland Working Paper No 9608.

Institute of International Finance, Inc (1998): Near-term prospects for emerging market economies, October.

International Monetary Fund (1998): "Chile's experience with capital controls". Annex IV of International Capital Markets. Washington, DC: International Monetary Fund.

Jonung, Lars (1992): "Swedish price-stabilization policy, 1931-1939 - The Riksbank and Knut Wicksell's norm", in Monetary policy with a flexible exchange rate. Stockholm: Sveriges Riksbank.

Jonung, Lars (1979): “Knut Wicksell's norm of price stabilization and Swedish monetary policy in the 1930s". Journal of Monetary Economics, Vol 5, pp 459-96.

Kapstein, Ethan B (1994): Governing the global economy. Cambridge, MA: Harvard University Press.

Kapstein, Ethan B (1992): "Between power and purpose: central bankers and the politics of regulatory convergence". International Organization, 46(1), pp 265-87.

Keynes, John Maynard (1936): The general theory of employment, interest and money. London: Macmillan.

Keynes, John Maynard (1923): A tract on monetary reform. London: Macmillan.

Kim, Ki-ho (1998): "US inflation and the dollar exchange rate: a vector error correction model". Applied Economics, 30, pp 613-9.

Klein, David (1998): "Transmission channels of monetary policy in Israel”. BIS Policy Papers No 3, January, pp 127-9.

Murray, John, Simon van Norden and Robert Vifusson (1996): "Excess volatility and speculative bubbles in the Canadian dollar: real or imagined?" Bank of Canada Technical Report No 76.

Murray, John and Rhita Khemani (1989): "International interest rate linkages and monetary policy: a Canadian perspective". Bank of Canada Technical Report No 52.

Obstfeld, Maurice and Kenneth Rogoff (1996): Foundations of international macroeconomics. Cambridge, MA: MIT Press.

Padoa-Schioppa, Tommaso and Fabrizio Saccomanni (1994): "Managing a market-led global financial system", in Kenen (ed), Managing the world economy: fifty years after Bretton Woods. Washington: IIE, September, pp 235-68.

Poole, William (1970): "Optimal choice of monetary policy instruments in a simple stochastic macro model”. Quarterly Journal of Economics, 84, pp 197-216.

Rivera-Batiz, Francisco L and Luis A Rivera-Batiz (1995): International finance and open economy macroeconomics. 2nd ed, New York: Macmillan.

Sarel, Michael (1996): "Nonlinear effects of inflation on economic growth". IMF Staff Papers, Vol 43, pp 199-215.

Selody, Jack (1990): "The goal of price stability: a review of the issues". Bank of Canada Technical Report No 54. 
Svensson, Lars E O (1997): "Inflation forecast targeting: implementing and monitoring inflation targets". European Economic Review, Vol 41, pp 1111-46.

Turner, Philip (1995): “Capital flows in Latin America: a new phase?" BIS Economic Papers No 44, May.

White, William R (1998a): "Crisis "contagion" in Asia: causes and preventive measures" in Capital adequacy regulation as an instrument for the regulation of banks - from the Basle Accord of 1988 to.... Special Volume of the Swiss Journal of Economics and Statistics, 3 July, Basle, pp 722-33.

White, William R (1998b): "Promoting international financial stability: the role of the BIS", in Teunissen (ed), Regulatory and supervisory challenges in a new era of global finance, Forum on Debt and Development (FONDAD).

White, William R (1994): "System risk and derivatives: can disclosure help?", in Special Paper No 66, London School of Economics. 




\section{Recent BIS Working Papers}

No.

50

November 1997

51

November 1997

52

January 1998

53

March 1998

54

June 1998

55

June 1998

56

June 1998

57

July 1998

58

November 1998

59

November 1998

60

November 1998

61

November 1998

62

March 1999

63

March 1999

64

March 1999

65

April 1999
Title

The euro and the dollar

Forecast errors and financial developments

Inflation and disinflation in Iceland

Exchange rate regimes and inflation and output in

Sub-Saharan countries

The coming transformation of continental European banking?

Spread overreaction in international bond markets

Commercial banks in the securities business: a review

One-step prediction of financial time-series

The importance of bank seniority for relationship

lending

Portfolio selection using fuzzy decision theory

Output gap uncertainty: does it matter for the Taylor rule?

Foreign direct investment and employment in the industrial countries

The pricing of bank lending and borrowing: evidence from the federal funds market

Microeconomic inventory adjustment and aggregate dynamics

Precarious credit equilibria: reflections on the Asian financial crisis

Higher profits and lower capital prices: is factor allocation optimal?
Author

Robert N McCauley

Palle S Andersen

Palle S Andersen and

Már Guðmundsson

Marc Klau

William R White

Gregory D Sutton

João A C Santos

Srichander

Ramaswamy

Stanley D Longhofer and João A C Santos

Srichander

Ramaswamy

Frank Smets

P S Andersen and P Hainaut

Craig H Furfine

Jonathan McCarthy and Egon Zakrajšek

Joseph Bisignano

P S Andersen, M Klau and $\mathrm{E}$ Yndgaard 


ISSN 1020-0959 